\title{
TACKLING THE MEASUREMENT OF CROSS-BORDER COOPERATION INTENSITY: AN EMPIRICAL EXAMPLE ON THE HUNGARY-CROATIA BORDER
}

\author{
Zoltán PÁMER \\ ${ }^{a}$ Centre for Economic and Regional Studies, Institute for Regional Studies, H-7621 Pécs, Papnövelde u. \\ 22., pamer.zoltan@krtk.hu
}

Cite this article: Pámer, Z. (2021). Tackling the measurement of cross-border cooperation intensity: an empirical example on the Hungary-Croatia border. Deturope. 13(2): 125-138.

\begin{abstract}
Although cross-border cooperation has traditionally been treated as a research issue of geopolitics and governance, use of data from European Union (EU) funded Interreg programmes opened up opportunities for comparative and in-depth analysis. The importance of Interreg programmes, as instruments of the European Territorial Cooperation goal, has been constantly on the rise since its inception as INTERREG Community Initiative, then becoming part of the cohesion policy mainstream in 2007. In the 2021-2027 programming period, for first time since its setup, Interreg has received lower funding, which requires a higher stress on cooperation and thematic concentration. When defining funding priorities of programmes, besides "general" factors (development needs, stakeholders' preferences, regulation constraints), the crossborder factor - i.e. how projects contribute to cooperation as such - should be also taken into consideration. Therefore, allocation should prefer thematic areas (priorities) where cooperation is likely to be more intensive. Intensity of cooperation, as a composite indicator, may be generated from various parameters that may be measured in case of implemented projects, on the basis of Interreg programme data.

The paper aims to provide a simple yet transparent methodology on how the intensity of cross-border cooperation may be measured and how different thematic areas may be ranked in terms of their contribution to cooperation. The first part of the study presents an overview of 'border studies' from different aspects and the selected target area concerned. It is followed by a summary of the evolution of European Territorial Cooperation, highlighting the main milestones and particularities of the regulation for the 2021-2027 programming period. The following part lays down the applied methodology: composition of cross-border cooperation intensity indicator and the five sub-indicators. The results are presented through the example of projects financed by the Interreg V-A Hungary-Croatia Cooperation Programme 2014-2020. The final part of the paper summarises the lessons learned and their replicability.
\end{abstract}

Keywords: cohesion policy, cross-border cooperation, cooperation intensity, Hungary, Croatia.

\section{INTRODUCTION OF THE PROBLEM AND THE TARGET AREA}

The interpretation of the nature and possible forms of cross-border cooperation has been investigated from several aspects by various scholars. A significant part of the research output focuses on theoretical, conceptual background (Nemes Nagy, 1998; Kolossov, 2015), as well as the geopolitical context (Martinez, 1994; Scott, 2015). Alongside the accelerating European 
integration process and the establishment of cross-border institutions governance and public policy issues have also been investigated (Perkmann, 2003; Scott-Liikanen, 2010 etc.). The added value of cross-border cooperation in the case of urban areas has been examined by the Metroborder project (ESPON, 2010), while Uszkai (2015) defined the influencing factors of cross-border integration.

The Hungary-Croatia border - which will be used for the presentation of the method -, as presented by Bali (2012), may be defined as an independent border region according to the categorisation of Martinez (1994), however - as Pámer (2019a) noted - there are also remnants of the co-existing past, but also some signs of integration, in particular in areas of some gateway towns. On the other hand, according to Rácz (2019), the Hungary-Croatia border area lacks significant cities and cities with advanced producer service (Döbrönte, 2018). This situation is aggravated by the fact that despite being an internal EU-border, Croatia's Schengen accession has not taken place yet. On the other hand, according to another scholar, the border area's main city, Pécs, by Hungarian standards was found relatively active in various forms of cross-border governance (Fekete, 2020). For the Hungary-Croatia border area, in terms of methodology, geopolitical considerations have been combined with Interreg-data based analysis on cooperation partnerships by Rácz (2017), and a comparative analysis of various levels of territorial governance in a wider territorial coverage has also been performed, also based on Interreg programme data by Pámer (2019b).

In order to further elaborate the practical approach and conceptualise priority setting and decision-making in cross-border cooperation policies, the paper attempts to present a simply applicable methodological tool for the measurement of cooperation intensity in various thematic areas. The main hypothesis of the paper is that dimensions of cooperation may be defined on the basis of cross-border cooperation data, and a composite indicator may also be developed. The method will be tested through the data available for the Interreg V-A HungaryCroatia Cooperation Programme financed by the EU in the 2014-2020 programming period.

\section{THE EVOLUTION OF INTERREG AND CROSS-BORDER COOPERATION}

Border areas are usually considered as peripheral regions isolated from their hinterlands and lagging behind in terms of economic and social development. Europe, with its fragmented structure of nation-states implies that most of Europe's regions are border regions. The European integration process, from its very beginning, triggered the border issue: integration of the European national economies in line with their tcomparative advantages. The role of 
border regions has even been strengthened after the accession of new member states to the EU in 2004 when countries of below-average size and land-locked position have become members.

European cohesion policy from its inception in 1975 has put a clear stress on the catchingup of the regions lagging behind. In 1984 the tool of Community Initiatives was introduced, more specifically, the INTERREG Community Initiative launched in 1998 targeting border regions (Harguindéguy \& Bray, 2009). In the first programming period (1990-1993) preference was dominantly on border areas of the Objective 1 cohesion regions (AEBR, 1997). The Maastricht Treaty was an important milestone in the establishment of the legal background of cross-border cooperation, through the promotion of the subsidiarity principle, enabling that designation of development programmes - including cross-border ones -in line with locally defined objectives. The INTERREG II initiative (1994-1999) set up the pillar system of INTERREG, separating cross-border cooperation from wider, transnational cooperation schemes. The pillar system has been more fine-tuned in the 2000-2006 programming period, where cross-border cooperation (pillar A), transnational cooperation (pillar B) and interregional cooperation (pillar C) were distinguished (INTERACT, 2015). In this period the role of the subnational level has been strengthened (Harguindéguy \& Bray, 2009): the representatives of border regions have been more operationally involved in programming, project selection and monitoring. In this programming period the 2004 accession new member states were already able to participate, albeit in a limited timeframe and obtaining somewhat limited financing. Since 2007 the European Territorial Cooperation (ETC) has been declared as 'Objective 3' of Cohesion Policy, cross-border cooperation - instead of Community Initiative - has become a part of the EU structural policy’s mainstream (Pámer, 2011).

Cross-border cooperation has been an important tool in the Europeanisation of peripheries (Scott \& Liikanen, 2010) already prior to the 2004 accession. Interreg Neighbourhood Programmes played a key role along Eastern borders of the EU, as has been revealed by several scholars (see Dołzbłasz, 2018) for Poland-Russia along the Eastern border and Nagy (2020) for the Southern border with Serbia. Euroregions established in the peripheries of the EU (Perkmann, 2007) were a tool practicing multi-level governance, the exchange of practices and the reduction of regional disparities (Popescu, 2008). As highlighted by Scott (2013), crossborder cooperation, in general, is considered as a special tool of the transmission of European values, a part of the progressive identity of the EU, however it might be criticised as cooperation is interest-driven and substitutes other funding sources (Scott, 2013). In the target area of the paper several scholars highlighted the added value of cross-border cooperation programmes, 
including Lados (2005) for Austria-Hungary, Csapó et al. (2015) for Hungary-Croatia or Zimmermann, Kubik (2003) for Slovenia-Austria.

\section{EUROPEAN TERRITORIAL COOPERATION AT PRESENT}

The funding of Interreg, and hence cross-border cooperation has been on a permanent rise since its very beginning (Table 1). Although Interreg is acknowledged as a distinctive tool of strengthening European integration, and it is important to maintain, two important changes in the approach may be detected. The first is a shift in its focus. The dilemma whether cross-border cooperation should resolve cohesion problems of generally undeveloped border regions through the provision of more funding; or rather stimulate the elimination of various obstacles, thus enhancing the efficiency of cooperation between various actors, seems to be resolved. According to a communication of the European Commission "Interreg is a policy tool to improve the situation and not a mere funding tool for the benefit of local authorities" (Interact, 2019; 10). Accordingly, funding for cross-border cooperation - for the first time since its inception - has been somewhat decreased (Table 1), putting bigger weight on transnational cooperation in line with macroregional strategies, rather than financing projects of bi- or trilateral cross-border programmes.

Table 1 The evolution of Interreg funding

\begin{tabular}{|l|c|c|}
\hline Programming period & No. of member states & Total funding (million EUR) \\
\hline $1990-1993$ & 11 & 4875 \\
\hline $1994-1999$ & 11,15 & 3600 \\
\hline $2000-2006$ & 15,25 & 4875 \\
\hline $2007-2013$ & 27,28 & 8700 \\
\hline $2014-2020$ & 28 & 8900 \\
\hline $2021-2027$ & 27 & 8050 \\
\hline
\end{tabular}

Source: own edition based on INTERACT $(2015 ; 8)$ and EC (2021a; 89).

Apart from limited funding the new period brings several further novelties that should be reflected in the new programme. Limited funding requires more accurate thematic concentration. In the new regulation of the European Regional Development Fund and the Cohesion Fund the previously applied 11 thematic objectives have been regrouped into five thematic objectives (PO1 - smart, PO2 - green, PO3 - connected, PO4 - social, PO5 - closer to citizens - EC, 2021b). Besides, the new Interreg regulation has introduced the so-called 
Interreg-specific objectives ('better cooperation governance' and 'a safer and more secure Europe' - EC, 2021c). According to the latest agreed draft, regulations application of PO2 ('a greener low-carbon...') and PO4 ('a more social Europe...') shall be compulsory in each new cross-border programme, further POs may be selected upon availability of funding. However, inside the individual POs there are several specific objectives that may cover a very wide array of activities. The isntroduction of the approach of functional areas makes territorial allocation of funding more flexible, focusing rather on the impacts of the project on the border area than on the origin of individual beneficiaries. This may enable the more intensive involvement of centrally organised state bodies that located outside the border areas, and also academic institutions carrying out research in the border areas but registered outside their borders.

The allocation of funding between member states has been calculated on the basis of the population living in the NUTS 3 target areas - similarly to previous programmes - however in the 2021-2027 period the calculation method has been changed, as the population living in the $25 \mathrm{~km}$ strip of the border has received a greater weight. Therefore, in particular countries with low population density that tend to have even less densely populated border areas, have to face a significant cut in the available funding.

The selection of priorities during the programming phase usually takes place within the triangle of local development needs, stakeholders' preference and regulation constraints (Figure 1). In the programming process development needs should be defined through a detailed and focused situation analysis, which is an important tool to justify the priority choices. Stakeholders' preferences may be channelled through various tools, e.g. open questionnaire surveys, interviews with selected key stakeholders, workshops organised either on territorial or thematic bases. Regulation constraints may vary, depending on European legislation, strategies, policy guidelines, etc. The relationship between the three corners of this triangle depends on the governance approach of the involved countries: their weight may be different even in the single partner countries, which may generate a complicated puzzle to solve.

Cross-border development programmes differ from "mainstream" programmes, as they need to comply with the cross-border factor as well. On one hand, it should be justified that cooperation is possible in the selected priority areas; but the added value of cooperation in the selected priority areas must also be proved. Thus, in order to make proper strategic choices, through taking into consideration the cross-border factor, intensity of cooperation should be somehow tackled: in case of certain development areas or types of projects. 
Figure 1 The triangle of priority selection in programming phase

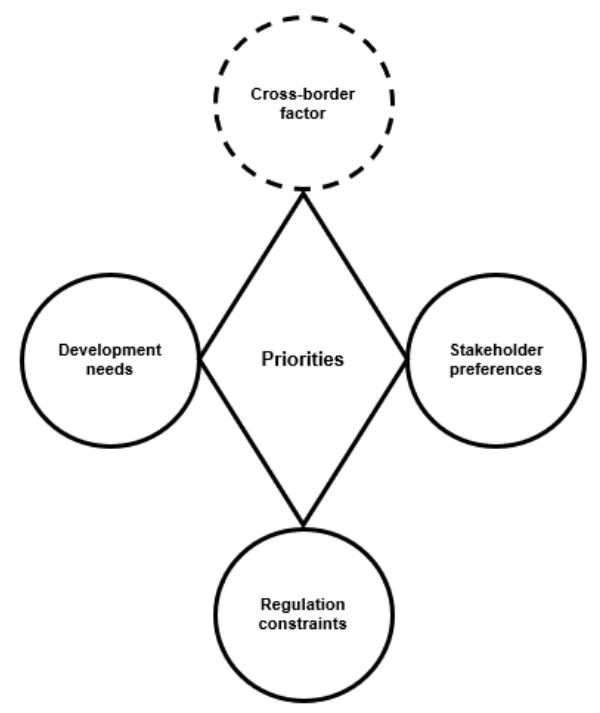

Source: Own edition.

\section{TACKLING COOPERATION INTENSITY: METHODOLOGY AND DATA}

The aim of the presented empirical research is to demonstrate how intensity of cooperation may be measured in various thematic areas on a sample of cross-border projects. The analysis has been carried out on the sample of projects contracted and implemented in the Interreg $\mathrm{V}-\mathrm{A}$ Hungary-Croatia Cooperation Programme 2014-2020. The database has been made available by the Joint Secretariat of the programme, for helping the programming process for the 20212027 period, where the author, as a key expert has been part of the programming team of Logframe Consulting Office in Hungary.

For the sake of the analysis projects had to be grouped into different categories, according to thematic areas. As a very segmented thematic grouping of the financed projects would generate a high number of categories with a small number of projects in each category, the analysis has been carried out on the basis of the components financed in the programme. These were the following:

- Tourism infrastructure projects that were further broken down to $a$ ) cycling infrastructure projects, b) other tourism attractions and $c$ ) thematic routes, which include projects with more sporadic cooperation with smaller budget;

- Nature protection projects aiming at the restoration of ecological diversity;

- SME development projects;

- Cooperation projects for high education institutions; 
- Other educational projects (pre-school, primary, secondary and vocational);

- Other various thematic cooperation projects;

- People-to-people cooperation projects.

The investigated cooperation programme, through altogether two "general" calls (multithematic for non-profit organisations) financed altogether 105 projects, which have been analysed on basis of the data included in the submitted project proposals. Besides the non-profit projects the altogether 20 selected SME projects ("B Light scheme") were also analysed, along the same criteria. The database included 125 projects. The so-called strategic projects, which were not selected through open calls but on basis of Monitoring Committee decision in some particular thematic areas, were excluded from the analysis.

Measurement of cooperation intensity has been done through the generation of five parameters measured on a simple scale of $0-2 ; 0$ being the weakest in the category, 1 representing a medium or average intensity of that category, and 2 the highest and most intensive cooperation.

- Physical proximity to the border: how are project partners concentrated in the border area? We assume a more proximate location to the border implies more intensive cooperation and more added value for the border region in question.

- Joint activities: how intensive is the cooperation during project implementation? It is assumed that if more project activities are implemented by partners from each side of the border, the cooperation is more intensive.

- Organisational compatibility: how similar are the partner organisations to each other? It is assumed if cooperating partners are compatible in terms of competences and institutional setting, cooperation is more intensive and partnership may be easier to sustain after project closure.

- Financing balance: how similarly are partners' budgets composed? It is assumed that a more equal distribution of funding between the two sides of the border means more balanced cooperation and effect on the border region.

- Investment orientation: how similarly are "hard" elements (equipment and works) distributed in the project budget? It is assumed that if composition of the budget is similar between the two sides in terms of investment orientation, interest in a successful project is also similar on the two sides.

The five parameters and the corresponding values are described in detail in Table 2. 
Table 2 Composition of cross-border cooperation intensity indicator

\begin{tabular}{|c|c|c|}
\hline Parameter & Measurement & Score \\
\hline \multirow{4}{*}{$\begin{array}{l}\text { Physical proximity to } \\
\text { the border }\end{array}$} & Distance of partners from the border & 0-2 \\
\hline & $\begin{array}{l}\text { Close distance (equal or less than } 25 \mathrm{~km} \text { ) from border in case of all } \\
\text { partners }\end{array}$ & 2 \\
\hline & $\begin{array}{l}\text { Medium distance (more than } 25 \mathrm{~km} \text { but less or equal to } 40 \mathrm{~km} \text { ) from } \\
\text { border in case of any partner }\end{array}$ & 1 \\
\hline & Large distance (more than $40 \mathrm{~km}$ ) from border in case of any partner & 0 \\
\hline \multirow[t]{4}{*}{ Joint activities } & $\begin{array}{l}\text { Out of the listed project activities, apart from the two compulsory } \\
\text { activities (Activity 1: management and coordination; Activity 2: } \\
\text { promotion and communication) how many of them are } \\
\text { implemented jointly (including at least one partner from Hungary } \\
\text { and Croatia) }\end{array}$ & 0-2 \\
\hline & At least $75 \%$ of the activities are implemented jointly & 2 \\
\hline & Jointly implemented activities at least $50 \%$ but less than $75 \%$ & 1 \\
\hline & Jointly implemented activities below $50 \%$ & 0 \\
\hline \multirow[t]{4}{*}{$\begin{array}{l}\text { Organisational } \\
\text { compatibility }\end{array}$} & $\begin{array}{l}\text { Differences in the types of beneficiaries on the two sides of the } \\
\text { border }\end{array}$ & 0-2 \\
\hline & $\begin{array}{l}\text { The same types of beneficiaries are represented on each side of the } \\
\text { border (all partners belong to the same type or each type appears } \\
\text { symmetrically) }\end{array}$ & 2 \\
\hline & $\begin{array}{l}\text { On both sides one type appears symmetrically, but further types are } \\
\text { also included }\end{array}$ & 1 \\
\hline & $\begin{array}{l}\text { The project is implemented through incompatible types of partners on } \\
\text { the two sides }\end{array}$ & 0 \\
\hline \multirow[t]{4}{*}{ Financing balance } & $\begin{array}{l}\text { Similarity in sizes of the project parts on the two sides of the } \\
\text { border }\end{array}$ & 0-2 \\
\hline & Share of funding between the two sides $60-40$ or more equal & 2 \\
\hline & Share of funding between the two sides between $60-40$ and $2 / 3-1 / 3$ & 1 \\
\hline & Share of funding between the two sides $2 / 3-1 / 3$ or more & 0 \\
\hline \multirow[t]{4}{*}{$\begin{array}{l}\text { Investment } \\
\text { orientation }\end{array}$} & $\begin{array}{l}\text { Deviation in the share of investment-related budget lines (costs of } \\
\text { thematically relevant equipment and works) compared to the total } \\
\text { budget, on the two sides of the border }\end{array}$ & $0-2$ \\
\hline & $\begin{array}{l}\text { Share of investment-related costs within partners' budget differs with } \\
\text { less than } 10 \text { percentage-points }\end{array}$ & 2 \\
\hline & $\begin{array}{l}\text { Share of investment-related costs differs with } 10 \text { to } 20 \text { percentage- } \\
\text { points }\end{array}$ & 1 \\
\hline & $\begin{array}{l}\text { Share of investment-related costs differs with more than } 20 \\
\text { percentage-points }\end{array}$ & 0 \\
\hline \multicolumn{2}{|r|}{1} & 10 \\
\hline
\end{tabular}

Source: own compilation.

For the definition of organisational compatibility project partners have been grouped into the following categories:

- Public institutions on local level (local governments and their public bodies);

- Public institutions on regional level (local governments and their public bodies);

- Public institutions on national level (governmental bodies); 
- Research institutions established by public bodies, dealing with research, development and innovation;

- Universities or other public high education institutions;

- Other education and training institutions, including public pre-school, primary, secondary education and adult education institutions;

- NGOs: non-profit civil organisations (association, foundation) established by non-public actors;

- Private non-profit company: non-profit making companies established by non-public bodies;

- SMEs: private for-profit companies that were eligible for the SME scheme.

In case of the single project categories various application constraints were applied that may affect the scoring of the single projects:

- In case of tourism infrastructure projects partners with investment (in types $a$ ) and b)) should come from the $40 \mathrm{~km}$ strip of the border. This results, by default, in overall higher scores in case of these two sub-categories for physical proximity.

- In case of SME development projects applicants could be only SMEs, therefore here organisational similarity is scored obviously as 2 .

- In case of education-related projects application was not limited to education institutions, thus scoring rather varies in these categories.

\section{PRESENTATION OF THE RESULTS}

Calculation of the composite cross-border cooperation intensity indicator is based on five subindicators. Sub-indicators are generated as arithmetic averages of the parameter values given for the projects under the selected thematic area, in the rage of $0-2$. The composite indicator is the sum of the five sub-indicators, in the range of 0-10 (Table 3).

In terms of physical proximity, as expected, tourism infrastructure projects have been given the highest scores, however nature protection projects have also received rather high scores. This is due to the fact that nature conservation projects rather focused on the protected areas that are dominantly in the direct vicinity of the border (the Mura, Drava and Danube rivers). Surprisingly, SME cooperation projects - where such concentration was not expected - are also significantly concentrated in the close border area. The least physical concentration is seen in the case of education projects. This is caused by the fact that higher education institutions are often located outside the $25 \mathrm{~km}$ strip from the border. 
Table 3 Values of the sub-indicators and the cross-border cooperation intensity indicator in case of single project types

\begin{tabular}{|c|c|c|c|c|c|c|}
\hline \multirow{2}{*}{$\begin{array}{l}\text { Project categories } \\
\text { (thematic areas) }\end{array}$} & \multicolumn{5}{|c|}{ Sub-indicators } & \multirow{2}{*}{$\begin{array}{c}\text { Cross-border } \\
\text { cooperation } \\
\text { intensity }\end{array}$} \\
\hline & \begin{tabular}{|c|} 
Physical \\
proximity to \\
the border
\end{tabular} & $\begin{array}{c}\text { Joint } \\
\text { activities }\end{array}$ & \begin{tabular}{|c|}
$\begin{array}{c}\text { Organisational } \\
\text { compatibility }\end{array}$ \\
\end{tabular} & $\begin{array}{c}\text { Financing } \\
\text { balance }\end{array}$ & $\begin{array}{l}\text { Investment } \\
\text { orientation }\end{array}$ & \\
\hline $\begin{array}{l}\text { Tourism infrastructure } \\
\text { a) cycling } \\
\text { infrastructure }\end{array}$ & 1.83 & 0.83 & 1.50 & 1.50 & 2.00 & 7.67 \\
\hline $\begin{array}{l}\text { Tourism infrastructure } \\
\text { b) other tourism } \\
\text { attraction }\end{array}$ & 1.56 & 1.00 & 0.81 & 1.25 & 1.56 & 6.19 \\
\hline $\begin{array}{l}\text { Tourism infrastructure } \\
\text { c) Thematic routes }\end{array}$ & 0.92 & 1.25 & 1.42 & 1.25 & 1.92 & 6.75 \\
\hline Nature protection & 1.29 & 1.43 & 1.57 & 0.86 & 1.43 & 6.57 \\
\hline SME development & 1.20 & 1.65 & 2.00 & 1.30 & 1.65 & 7.80 \\
\hline $\begin{array}{l}\text { Cooperation of high } \\
\text { education institutions }\end{array}$ & 0.83 & 1.67 & 1.67 & 1.33 & 1.67 & 7.17 \\
\hline $\begin{array}{l}\text { Other educational } \\
\text { cooperation (pre-school, } \\
\text { primary, secondary and } \\
\text { vocational) }\end{array}$ & 0.88 & 1.36 & 1.16 & 1.52 & 1.72 & 6.64 \\
\hline $\begin{array}{l}\text { Other various thematic } \\
\text { cooperation }\end{array}$ & 0.74 & 1.79 & 1.21 & 1.74 & 1.84 & 7.32 \\
\hline $\begin{array}{l}\text { People-to-people } \\
\text { cooperation }\end{array}$ & 1.14 & 1.86 & 1.14 & 1.64 & 1.43 & 7.21 \\
\hline
\end{tabular}

Source: own edition.

In terms of the joint implementation of activities - unlike in the case of physical proximity - tourism development projects have performed rather poorly, as in these projects different partners carry out different, usually infrastructure-focused activities that often lack direct cooperation. In this parameter soft cooperation projects performed significantly better. Surprisingly high scores were given to SME cooperation projects proving that SMEs are more interconnected in such projects than tourism development actors.

For organisational compatibility, obviously, SME development projects have been rated the highest, as only SMEs were allowed to apply. Logically, higher education projects have been rated relatively high, just like nature protection projects that concentrated designated public bodies for nature conservation that were sometimes teamed up with NGOs or local governments. The lowest level of compatibility was detected in the case of major tourism (not cycling) infrastructure development projects.

In terms of financing balance, small-scale cooperation projects (thematic and people-topeople cooperation) proved to be the most budget-balanced. On the other hand, nature conservation projects generated a rather unbalanced distribution of funding. 
Concerning investment-orientation, cycling infrastructure projects were obviously the most investment-oriented, however smaller scale tourism cooperation projects have shown higher (1.92) spending on supplies and works than the component $(b))$ directly dedicated to major investment projects (1.56). Surprisingly, small thematic cooperation projects proved to be the most investment-oriented. This implies that allowing supply and works spending in soft projects may generate heavily investment-oriented budgets. This may justify the thesis of Scott (2013) that cross-border cooperation is often interest-driven and investment-driven, in order to substitute other funding sources. This issue was also investigated by Pámer (2019a), in order to identify the major investors in cross-border cooperation. The lowest level of investmentorientation is detected, also surprisingly, in case of nature protection projects, where soft elements (such as awareness raising) represented a significant share in the budget.

Concerning the composite indicator, highest values of cooperation intensity have been detected in the case of SME cooperation projects (7.80) and cycling infrastructure projects (7.67). In both of these two categories there are factors that produced outstanding parameter values. In case of cycling infrastructure, development of physical proximity and heavy investment-orientation; in case of SME projects organisational homogeneity and the interconnectivity of activities are worth stressing. The lowest cooperation intensity value has been produced by the "other" tourism attraction development projects that were really a "mixed bag", with a high level of organisational heterogeneity and lack of connectivity in project activities. Further weaker performing project categories were the "other educational" projects that attracted the most various types of beneficiaries located dispersely in the programme area.

As a conclusion, dimensions of cross-border cooperation and the cross-border cooperation intensity indicator is possible to define with the help of Interreg data. The analysis shows significant differences in the case of the various thematic areas, that are partly caused by particularities of the border area (territorial features, institutional background) and the programme itself the data is taken from (programme rules and funding conditions). Therefore, although the methodology is easily replicable, the results must be interpreted in the context of the programme concerned, as they significantly influence the results.

\section{LESSONS LEARNED AND REPLICABILITY}

As the provided methodology is very simple, it provides an easy-to-use template for the measurement of cooperation intensity, which is an important aspect when deciding to which policy areas or project types should be preferred that may best satisfy the cross-border factor, 
i.e. provide the biggest benefit from a cooperation point of view. This tool also provides enables the quantification of cooperation as such, which may be used in evaluation and assessment exercises.

The outcome of the analysis, through this one example, shows that thematic concentration does have an added value. Tourism projects are often criticised as serving rather local needs and the activities of partners lack real coherence, the analysis has proven that the introduction of thematic concentration, along with territorial concentration - as was applied in case of cycling tourism projects - may generate higher cooperation intensity. Also, SME development has been for a long time "overlooked" as an odd element in cross-border cooperation, which should not support private interest, but rather serve the public good through non-profit organisations. The analysis has shown that surprisingly SME cooperation generates a high level of intensity, as SMEs were bound together to work on the development of the same product or service, in a rather symmetric cooperation manner. Also, the presented results may underpin or refute certain statements about the effectiveness and efficiency of publicly funded development policies, particularly those concerning direct SME subsidies and infrastructure. Thus, crossborder cooperation is a rather specific element of cohesion policy, where subsidies to certain thematic areas may be effective from a cooperation intensity point of view, while questionable from an economic impact point of view.

Even if the outcome of the analysis should be understood in the context of the investigated programme, the sensitivity of the method may prove the efficiency of certain conditions set by the programme. As the method is replicable, it would have an added value to perform it on a larger project database, including several border regions of a microregion (Central Europe), or for the same border area, overviewing projects of more than one programming period.

\section{Acknowledgement}

Research for this publication has been supported by the Hungarian National Research, Development and Innovation Office - NKFIH grant 134903 (Geopolitical Processes and Imaginaries in Central Europe: States, Borders, Integration and Regional Development).

\section{REFERENCES}

AEBR (1997). The EU Initiative INTERREG and future developments. Association of European Border Regions. Retrieved July 16, 2018, from https://www.aebr.eu/files/publications/interreg_97.en.pdf

Bali, L. (2012). A horvát-magyar határon átnyúló kapcsolatok jelene és jövője. BudapestSzepetnek: Underground Kiadó. 
Csapó, J., Čelan, T. J., \& Trócsányi, A. (2015). A határmenti együttmüködés hatásai a területi fejlődésre a magyar-horvát szakasz példáján az EU tervezési mechanizmusának tükrében (2007-2013) [Impacts of cooperation in border areas on territorial development on example of the Hungary-Croatia border area, in light of the EU planning mechanism (2007-2013)]. Területfejlesztés és Innováció, 9(2), 22-31.

Dołzbłasz, S. (2018). A network approach to transborder cooperation studies as exemplified by Poland's eastern border. Geographia Polonica, 91(1), 63-76. https://doi.org/10.7163/ GPol.0091

Döbrönte, K. (2018). The impact of locational strategies of advanced producer service firms on the metropole cities' economic positions in Central Europe. Deturope, 10(3), 70-89.

EC (2021a). Regulation (EU) 2021/1060 of the European Parliament and of the Council of 24 June 2021 laying down common provisions on the European Regional Development Fund, the European Social Fund Plus, the Cohesion Fund, the Just Transition Fund and the European Maritime, Fisheries and Aquaculture Fund and financial rules for those and for the Asylum, Migration and Integration Fund, the Internal Security Fund and the Instrument for Financial Support for Border Management and Visa Policy.

EC (2021b). Regulation (EU) 2021/1058 of the European Parliament and of the Council of 24 June 2021 on the European Regional Development Fund and on the Cohesion Fund.

EC (2021c). Regulation (EU) 2021/1059 of the European Parliament and of the Council of 24 June 2021 on specific provisions for the European territorial cooperation goal (Interreg) supported by the European Regional Development Fund and external financing instruments.

ESPON (2010). Metroborder - Cross-border polycentric Metropolitan Regions. Targeted Analysis 2013/2/3. Final Report. ESPON \& University of Luxembourg.

Fekete, D. (2020). A magyar határ menti nagyvárosok határon átnyúló kormányzásának vizsgálata az EGTC-kben és INTERREG-projektekben betöltött szerepük alapján [Governance characteristics of big cities in border regions of Hungary based on their role in EGTCs and INTERREG projects]. Tér és Társadalom, 34(3), 224-243. https://doi.org/10.17649/TET.34.3.3190

Harguindéguy, J.-B., \& Bray, Z. (2009). Does cross-border cooperation empower European regions? The case of INTERREG III-A France - Spain. Environment and Planning C: Government and Policy, 27, 747-760.

INTERACT (2015). Fact Sheet; Historical view of Interreg / European Territorial Cooperation. Retrieved July 16, 2018, from www.interact-eu.net/download/ file/fid/2902 Interact (2019). Territorial approach post 2020. Input to Transitioning. 09-10 December 2019, Frankfurt/Main, DE, Bernard Schausberger. Retrieved January 21, 2021, from http://www.interact-eu.net/download/file/fid/18497.

Kolossov, V. A. (2015). Theoretical approaches in the study of borders. In Sevastianov, S. V., Laine, J. P., \& Kireev, A. A. (eds.): Introduction to Border Studies. Far Eastern Federal University, Dalnauka, Vladivostok.

Lados, M. (2005). Programértékelés a 2000. évi Magyarország-Ausztria Phare CBC Kisprojekt Alap példáján [Programme evaluation on example of the year 2000 Hungary-Austria Phare CBC Small Project Fund]. Tér és Társadalom, 19(2), 101-126.

Martinez, O. J. (1994). The Dynamics of Border Interaction: New Approaches to Border Analysis. In Schofield, C. H. (Ed.): World Boundaries. Volume I Global Boundaries (pp. 1-15). London, New York. Routledge.

Nagy, I. (2020). Cross-border cooperation on the external borders of the EU and the impact of the received $\mathrm{EU} \mathrm{CBC}$ funds on AP Vojvodina/Serbia. Belgeo, 2. https://doi.org/10.4000/belgeo.38732 
Nemes Nagy, J. (1998). A tér a társadalomkutatásban. Budapest: Hilscher Rezső Szociálpolitikai Egyesület.

Pámer, Z. (2011). The possibilities of implementing the European Grouping of the Territorial Cooperation in South Transdanubia. In Ágh A., Kaiser T., \& Koller B. (Eds.): The New Horizons of the Cohesion Policy in the European Union: the Challenge of the Danube Strategy (pp. 176-194). Budapest: Blue Ribbon Research Centre King Sigismund College.

Pámer, Z. (2019a). A területi kormányzási struktúrák hatása a határon átnyúló együttmüködésre - négy határrégió összehasonlitó elemzése. Pécs: PTE Közgazdaságtudományi Kar Regionális Politika és Gazdaságtan Doktori Iskola. http://hdl.handle.net/11155/2078

Pámer, Z. (2019b). How governance counts? Comparative analysis of activity and funding patterns of Central European Cross-border Cooperation Programmes. EUROPA XXI, 35, 111-126. http://doi.org/10.7.7163/Eu21.2018.35.7

Perkmann, M. (2003). Cross-border Regions in Europe. Significance and Drivers of Regional Cross-border Cooperation. European Urban and Regional Studies,10(2), 153-171. SAGE Publications.

Perkmann, M. (2007). Policy entrepreneurship and multilevel governance: a comparative study of European cross-border regions. Environment and Planning C: Government and Policy, $25,861-879$.

Popescu, G. (2008). The conflicting logics of cross-border reterritorialization: Geopolitics of Euroregions in Eastern Europe. Political Geography, 27, 418-438.

Rácz, Sz. (2017). Main characteristics of Hungarian-Croatian political relations and CrossBorder Co-operations. Geographica Pannonica, 21(1), 54-67. https://doi.org/10.18421/ GP21.01-05

Rácz, Sz. (2019). Development Processes of Regional Centres in Central and Southeast Europe - From State Socialism to Dependent Market Economies. Deturope, 11(2), 92-100.

Scott, J. W. (2013). Territorial Cohesion, Cross-border Co-operation and the EU's Political Identity: A Brief Observation. In Pálné Kovács, I., Scott, J., \& Gál, Z. (Eds.), Territorial Cohesion in Europe - For the 70th anniversary of the Transdanubian Research Institute (pp. 73-84). Pécs: Institute for Regional Studies, Centre for Economic and Regional Studies, Hungarian Academy of Sciences.

Scott, J. W. (2015). Bordering, Border Politics and Cross-Border Cooperation in Europe. In Celata, F., \& Coletti, R. (Eds.). Neighbourhood Policy and the Construction of the European External Borders, GeoJournal Library 115, DOI 10.1007/978-3-319-184524 2.

Scott, J. W., \& Liikanen, I. (2010). Civil Society and the 'Neighbourhood' - Europeanization through Cross-Border Cooperation? In Scott, J. W., \& Liikanen, I. (Eds.), European Neighbourhood through Civil Society Networks? London: Routledge.

Uszkai, A. (2015). Measurement levels of the spatial integration - Suggestion for a CentralEuropean Factor Group. Deturope, 7(2), 65-80.

Zimmermann, F. M., \& Kubik, K. (2003). Grenzüberschreitende Kooperationen: Der Raum Graz - Maribor [Cross-border cooperation: the Graz - Maribor area]. Ländlicher Raum 3/2003. Retrieved March 10, 2016, from https://www.bmlfuw.gv.at/dam/jcr:f5e2c70d7507-44dd-bba5-6254351bd795/Zimmermann_end2\%5B1\%5D.pdf. 